\title{
Perceived Social Support and Subjective Well-being of Ex-service People of the Indonesian Defence Forces
}

\author{
Setiasih and I Gusti Ayu Putu Mas Jayanti \\ Faculty of Psychology \\ Universitas Surabaya
}

\begin{abstract}
Retired people often feel unhappy (have low subjective well-being - SWB). Perceived social support is a form of stress buffer, which can play the role of an additional resource, for an individual facing the challenges of life (as a pensioner). The goal of this study is to ascertain the connections between perceived social support and SWB for ex-servicemen and women of the TNI. The retired TNI subjects $(N=40)$ live in Denpasar (Bali). Data collection was conducted using the Interpersonal Support Evaluation List, the Satisfaction with Life Scale, and the Positive and Negative Effects Scale. Data analysis used the correlation technique of Pearson and Spearman. The results showed a significant positive correlation between perceived social support and life satisfaction $(r=.420 ; p=.007<.05)$ and a positive effect $(r=.667 ; p=.000$ $<0.05)$. There was no significant negative correlation shown between perceived social support and negative effects $(r=-.208 ; p=.119>.05)$.
\end{abstract}

Keywords: perceived social support, subjective well-being, TNI ex-servicemen and women

Individu yang pensiun seringkali merasa tidak bahagia (memiliki kenyamanan subjektif/ subjective well-being/SWB yang rendah). Kesan dukungan sosial (perceived social support) merupakan satu bentuk dapar stress (stress buffer) yang dapat berperan sebagai sumber daya tambahan bagi individu, dalam menghadapi tantangan hidup (masa pensiun). Tujuan penelitian ini adalah untuk mengetahui hubungan antara kesan dukungan sosial dan SWB pada purnawirawan TNI. Subjek purnawirawan TNI $(N=40)$ berdomisili di Denpasar. Pengumpulan data menggunakan Interpersonal Support Evaluation List, Satisfaction with Life Scale, dan Positive and Negative Affect Scale. Analisis data menggunakan teknik korelasi Pearson dan Spearman. Hasil menunjukkan korelasi positif signifikan antara perceived social support dan life satisfaction $(r=.420 ; p=.007<.05)$ dan positive affect $(r=.667 ; p=.000<.05)$. Korelasi negatif tidak signifikan ditunjukkan antara perceived social support dan negative effect $(r=$ $-.208 ; p=.119>.05)$.

Kata kunci: kesan dukungan sosial, kenyamanan subjektif, purnawirawan TNI

One of the life events which will be faced by people in middle-age is retirement, that is the separation of a person is from his or her employment, in line with the pensionable age determined in the retirement regulations. In connection with his or her work, a number of positive matters (benefits) which an individual possesses are lost (no longer exist). Several of those positive matters include: income, routine, as a supplier of a regulated life, a contex for social interaction, a significant basis for status and personal identity, as well as experience, all of which can provide a sense of accomplishment (Friedman \& Havighurst, as cited

Correspondence concerning this article should be addressed to Setiasih, Faculty of Psychology Universitas Surabaya. Jalan Raya Rungkut Mejoyo (Kalirungkut) Surabaya 60293. E-mail: setiasih_siegit@yahoo.com in Herzig, 2014).

Study results discussing the connections between retirement and mental health indicate a contradiction between one and the other. Herzig (2014) stated that retirement is a life event which can be full of stress, but retirement also reduces pressures related to employment. The study by Drentea et al., (as cited in Butterworth et al., 2006) indicated that retirement will reduce workplace-related stress, and raise the sense of personal control of an individual. Heller-Sahlgren (2017) stated that retirement has a negative impact on the mental health of an individual, whilst the results of study by Moen (as cited in Butterworth et al.) indicated that retirement has a negative impact through the loss of the positive benefits of employment, 
for instance financial stability, a sense of purpose, and social activity. According to Richardson et al., (as cited in Butterworth et al., 2006) retirement is connected to an increase in depression or the symptoms of anxiety, however a study by Latif (2011) and Mein et al. (as cited in Butterworth et al.) indicate that retirement is followed by an improvement in the mental health of the individual.

Results of other studies indicate that the life satisfaction of a person increases during the first year of retirement, but reduces in the second year (Henning, Hansson, Berg, Lindwall, \& Johansson, 2017; Lucas, Daniel, Guadalupe, Massana-Cardoso, \& Vicente, 2017). This situation is as yet unclear, as to whether the changes are short-term, being a "honeymoon effect", or long-term (Henning et al.).

van der Heide, van Rijn, Robroek, Burdorf, and Proper (2013) stated that the stress for the individual undergoing involuntary retirement is greater than a person undergoing voluntary retirement. This can be understood because the voluntary retirement experienced by a financially "safe" person (one who has savings, or sufficient retirement funds), whereas involuntary retirement is experienced by someone "forced" to retire because of having reached retirement age, or because of health, or internal company problems.

Acceptance of retirement for a serviceman or woman tends to be more difficult, particularly for early retirement, or voluntary retirement. There is the possibility for a service person, living within a very tight hierarchy or chain of command and high-level discipline, that retirement may be seen as "a slow death", particularly for a service person who has held rank. Results of study by Kypraiou et al. (2017), with male veteran retirees, in Greece, indicated that there were $3.8 \%$ suffering serious depression, and $23.2 \%$ suffering mild to mid-level depression. Results of a study by Pflanz (2001), on 85 military outpatients at the Wilford Hall US Airforce Medical Center Mental Health Clinic, indicated that $60 \%$ were suffering workrelated stress, and that $52 \%$ of servicemen suffering work-related stress also suffered emotional stress.

A report by the U.S. Joint Mental Health Advisory Team (JMHAT 7, 2011, as cited in Harms, Krasikova, Vanhove, Herian, \& Lester, 2013) stated that a combination of stress and acute traumatic experiences in, or as a result of, combat, suffered by American servicemen and women, indicated that $19.98 \%$ were suffering psychological problems.

Although a study on retirees shows inconsistent results, the fact that retirement is considered to be a stressful life event should not be ignored. Retirees generally suffer fear related to a reduction in their financial, health and social contact situations (Papalia, Sterns, Feldman, \& Camp, 2007). Despite this, retirees still hope to be able to enjoy their retirement, to feel happy, and to feel satisfaction in their lives.

Individual evaluation of happiness and life satisfaction can be seen from the presence of subjective well-being. According to Diener, Oishi, and Lucas (2003), subjective well-being is an emotional and cognitive evaluation related to the life being led by an individual, including what is considered to be happiness, peace, achievement/fulfillment, and satisfaction with life. According to Keyes, Ryff, and Shmotkin (2002), SWB is the individual's evaluation of life, regarding satisfaction and balance of positive and negative effects. From these two definitions, it may be seen that SWB is an individual's subjective evaluation of his or her own life. This means that people have differing standards of evaluation, even though they live in the same environment and experience the same events. SWB consists of two principle components, the cognitive domain (evaluation of satisfaction with life), and the affective domain (positive and negative emotions) (Lin, 2015). This implies that an individual having high SWB (happiness) is a person experiencing a greater satisfaction with life, and experiencing relatively more positive emotions than negative.

According to Diener and Seligman (in Siedlecki, Salthouse, Oishi, \& Jeswani, 2013), one consistent variable in predicting SWB is the quality of social relationships. A person who feels satisfied with his/ her social relationships more often feels happy (high SWB), and feels greater satisfaction with his/her life, compared to a person less satisfied with the quality of his/her social relations. A person feeling satisfied with his/her social relationships tend more easily to access and obtain support when it is required. In this matter, the quality of social relationships is reflected in the social support felt by the individual. Studies regarding the function (role) of the family of the serviceman or woman support the importance of social support as a source of protection, when a person is facing problems of a psychological nature. In this matter, the family is the principle source of social support for a serviceman or woman. (MHAT-5, 2008, as cited in Harms et al., 2013). As is known, for a serviceman or woman, besides suffering the stress experienced by people in general, he/she may also suffer postcombat stress. The forms of stress associated with combat arise from such situations as prolonged or short periods involved in combat, together with various other 
experiences which give rise to negative emotions, such as sorrow when he/she is wounded, or a friend is wounded or killed.

Social support is a multi-dimensional variable, comprising: (1) social embeddedness; (2) perceived social support; (3) received/enacted/actual support; and (4) provided support. The social support dimension which is the focus of this study, is perceived social support. Perceived social support is the conviction of an individual of the levels and quality of support available to him or her (Matsuda, Tsuda, Kim, \& Deng, 2014). Perceived social support can also be interpreted as a person's perception of the availability of resources having the potential to become sources of support, which may be accessed by the person concerned, when required.

The most important reason for making perceived social support the study focus is its ability in predicting subjective well-being (Matsuda, Tsuda, Kim, \& Deng, 2014). A study by Gülaçti (2010) indicated that perceived social support can be predictive of up to $43 \%$ of an individual's SWB. Other reasons are that perceived social support is one of the dimensions of social support which has an active role as a buffer in confronting stressful life events, and, at the same time, is the dimension which is most consistent in predicting the health of a person.

There is information which is able to demonstrate the active role of perceived social support as a buffer against stressful life events. This information compares perceived social support and actual social support. According to Matsuda, Tsuda, Kim, and Deng (2014), the perception of the availability of support is more important than actual support. Information which may be obtained, in relation to the comparison of perceived and actual support, is that when a person does not consider, or perceive, a source of support to be a source of support, then that source of support cannot be used.

There is a large amount of the latest literature which states that the important factor giving social support a role as a buffer against stress is the perception that others (reliable resources) will provide the required assistance (Cohen, 2004). The perception that others may be relied upon when confronting a difficult situation is a portion of perceived social support. On the basis of this outlook, the conviction that others will provide the required resources can increase the perceived ability to overcome challenges. This will later change a person's evaluation or viewpoint towards a situation, and reduce stress.

As a stress buffer, perceived social support may be seen as the four support functions perceived as being accessible for a person, when required. These four functions are: (1) appraisal support; (2) tangible support; (3) self-esteem support; and (4) belonging support, which may also assist in predicting the extent of the person's SWB.

Several results, and opinions stated by experts, provide strong evidence that perceived social support is capable of acting as a buffer against stressful life events, to the extent that it will assist a retired person in having high subjective well-being. As limited as the evaluation concerning the ease of access to, and the availability of, support is, it is able to assist people in confronting challenges in their lives and, at the same time, cause them to have high SWB. This increasingly strengthens the reason for this study making perceived social support a study variable related to subjective well-being, particularly for TNI retirees.

The aim of this study is to determine the connections between perceived social support and subjective well-being (life satisfaction, positive effects, negative effects). This study is also aimed at determining the function of perceived social support. What will have the maximum contribution for a TNI retiree (TNI-r) so that he or she has high SWB? As regards the hypothesis put forward in this study, it is: is there a connection between perceived social support and SWB (life satisfaction, positive effects, negative effects) for ex-TNI servicemen and women?

\section{Method}

\section{Study Participants}

The participants in this study retirees/ex-servicemen and women of the Indonesian Defence Force (Army), ranging in age from 53 to 65 years, who live in Denpasar, Bali.

\section{Data Collection}

Data collection was conducted with the assistance of a TNI-r (as key informant), who supplied information concerning TNI-r/pensioners who might become study participants.

The measurement implements employed in this study were three:

(1) The Interpersonal Support Evaluation List (ISEL), to measure perceived social support. The ISEL was compiled by Brummet, based on the study of Cohen and Hoberman (1983), and comprises an inventory de- 
signed for the general population, consisting of 40 statement points. Each function of perceived social support (appraisal, self-esteem, tangible, belonging) was measured using ten statements;

(2) Satisfaction with Life Scale (SWLS) is a scale to measure the global cognitive evaluation of a person's satisfaction with life (Diener, Emmons, Larsen, \& Griffin, 1985). The SWLS evaluation comprised five statements, with a range of responses from 1 (greatly disagree) to 7 (greatly agree). The SWLS used in this study was adapted from Diener et al. (1985);

(3) A Positive and Negative Affect Scale (PANAS) is used to measure the dimensions of positive and negative effects. The PANAS used in this study was an adaptation of that from Watson, Clark, and Tellegen (1988), consisting of twenty statements, with a response range from 1 (very rarely, or not at all) to 5 (very frequently).

\section{Data Analysis}

The nature of this study was correlationally quantitive. The data analysis used correlational testing from Pearson (parametric data testing) and Spearman (nonparametric data testing). Prior to the analysis, testing of the measurement implements was conducted (testing of content validity, involving expert judgement, reliability testing using the Alpha Cronbach method, and assumption testing (normality and linearity).

\section{Results}

The people acting as subjects in this study comprised 40 TNI ex-servicemen and women, nine females and thirty one males. All of the measurement implements, after being evaluated using expert judgement, then had their reliability tested. The results of reliability testing indicated that the three measurement implements used (ISEL, SWLS and PANAS) were classifiable as reliable. The Alpha Cronbach values produced for each measurement implement were: ISEL $=.840 ; S W L S=.689 ;$ PANAS (positive effects $=.827$; negative effects $=.804$ ).

The results of normality testing indicated that only the SWLS (life satisfaction) scale data which was classifiable as normal $(p=.200)$. Data from the PANAS scale was classified as abnormal, with respective values of $(p=.047)$ for positive effects and $(\mathrm{p}=.013)$ for negative effects.

Linearity testing produced the following results: the correlation between perceived social support and life satisfaction was linear $(p=.007)$. The correlation between perceived social support and positive effects was also linear $(p=.000)$. The correlation between perceived social support and negative effects showed a non-linear result $(p=.115)$.

The data analysis in this study, that is the variable of perceived social support (PSS), was correlated with each dimension of SWB (life satisfaction, positive effects, negative effects). Testing of the relationship between perceived social support and life satisfaction used Pearson parametric testing (normal data distribution). The testing of the relationship between perceived social support, positive effect, and negative effects used non-parametric Spearman testing (abnormal data distribution). Full results can be seen in Table 1 .

Table 1 shows that there is a significant positive relationship between perceived social support and life satisfaction $(r=.420 ; p=.007)$. The contribution of perceived social support to life satisfaction was $17.6 \%$. In this, the higher the perceived social support the individual had, the higher also is the life satisfaction he or she felt. The analysis results also showed there was a significant positive relationship between perceived social support and positive effects $(r=.667 ; p=.000)$, whilst perceived social support showed no significant relationship to negative effects $(r$ $=-.208 ; p=.199$ ).

Table 1

Results of Hypothesis Testing

\begin{tabular}{|c|c|c|c|c|}
\hline Variable & Sig. & $\begin{array}{c}(r) \\
\text { Pearson }\end{array}$ & $\begin{array}{c}(r) \\
\text { Spearman }\end{array}$ & Status \\
\hline $\begin{array}{l}\text { PSS - Life } \\
\text { satisfaction }\end{array}$ & .007 & .420 & 1 & $\begin{array}{l}\text { Significant } \\
\text { Correlation }\end{array}$ \\
\hline $\begin{array}{l}\text { PSS - Positive } \\
\text { effects }\end{array}$ & .000 & - & .667 & $\begin{array}{l}\text { Significant } \\
\text { Correlation }\end{array}$ \\
\hline $\begin{array}{l}\text { PSS - Negative } \\
\text { effects }\end{array}$ & 199 & - & -.208 & $\begin{array}{l}\text { Insignificant } \\
\text { Correlation }\end{array}$ \\
\hline
\end{tabular}

Table 2

Results of Testing of Sub-scales

Perceived Social Support and Life Satisfaction (LS)

\begin{tabular}{|c|c|c|c|}
\hline Sub-scale & Sig. & $\begin{array}{c}(r) \\
\text { Pearson }\end{array}$ & Status \\
\hline ppraisal support - LS & .029 & . 346 & \\
\hline Belonging support - LS & .075 & .285 & $\begin{array}{l}\text { Insignificant } \\
\text { Correlation }\end{array}$ \\
\hline Self-esteem support-LS & .083 & . 278. & $\begin{array}{l}\text { Insignificant } \\
\text { Correlation }\end{array}$ \\
\hline Tangible support - LS & .007 & .418 & $\begin{array}{l}\text { Significant } \\
\text { Correlation }\end{array}$ \\
\hline
\end{tabular}


Table 2 shows the analysis results between the four sub-scales of perceived social support and those of life satisfaction, these being that there is a significant positive correlation between life satisfaction and the sub-scales of perceived social support, particularly the appraisal support sub-scale $(r=.346 ; p=.029)$, and the tangible support sub-scale $(r=.418 ; p=007)$. There is an insignificant correlation between life satisfaction and the belonging support $(r=.285 ; p=.075)$, and self-esteem support ( $r=.278 ; p=.083$ ) sub-scales.

Table 3 shows that all sub-scales of perceived social support have significant positive correlations between positive effects and appraisal support $(r=.338$; $p=.004)$, belonging support $(r=.457 ; p=.000)$, selfesteem support $(r=.373 ; p=.001)$, and tangible support $(r=.401 ; p=.001)$. This shows that the subjects of this study will enjoy high positive effects if they have by someone who: can be persuaded to talk, to discuss problems and help seek the best strategy (solution) (appraisal support); can be persuaded to complete a joint activity (belonging support); can raise their convictions regarding their possessing the abilities to overcome problems or complete certain tasks (self-esteem support); or can give support or physical accompaniment, or support in the form of material goods or deeds (tangible support).

Table 3

Results of Correlation Testing - Perceived Social Support and Positive Effects (PA) Sub-scales

\begin{tabular}{llcc}
\hline \multicolumn{1}{c}{ Sub-scale } & Sig. & $(r)$ Spearman & Status \\
\hline Appraisal support - PA & .004 & .338 & Significant Correlation \\
Belonging support - PA & .000 & .457 & Significant Correlation \\
Self-esteem support-PA & .001 & .373 & Significant Correlation \\
Tangible support - PA & .001 & .401 & Significant Correlation \\
\hline
\end{tabular}

Table 4

Results of Testing of the Correlation Between the Sub-scales of Perceived Social Support and Negative Effects (NE)

\begin{tabular}{llcc}
\hline \multicolumn{1}{c}{ Sub-scale } & Sig. & $(r)$ Spearman & Status \\
\hline Appraisal support $-\mathrm{NE}$ & .242 & -.138 & Insignificant Correlation \\
Belonging support $-\mathrm{NE}$ & .465 & -.085 & Insignificant Correlation \\
Self-esteem support $-\mathrm{NE}$ & .011 & -.300 & Significant Correlation \\
Tangible support $-\mathrm{NE}$ & .981 & -.003 & Insignificant Correlation \\
\hline
\end{tabular}

Table 5

Frequency Distribution - Perceived Social Support (PSS) and Aspects of Perceived Social Support

\begin{tabular}{|c|c|c|c|c|c|c|c|c|c|c|}
\hline \multirow{3}{*}{ Category } & \multirow{2}{*}{\multicolumn{2}{|c|}{ PSS }} & \multicolumn{8}{|c|}{ Aspects of Perceived Social Support } \\
\hline & & & \multicolumn{2}{|c|}{$\begin{array}{c}\text { Appraisal } \\
\text { Support }\end{array}$} & \multicolumn{2}{|c|}{$\begin{array}{c}\text { Belonging } \\
\text { Support }\end{array}$} & \multicolumn{2}{|c|}{$\begin{array}{l}\text { Self-esteem } \\
\text { Support }\end{array}$} & \multicolumn{2}{|c|}{$\begin{array}{l}\text { Tangible } \\
\text { Support }\end{array}$} \\
\hline & $\mathrm{F}$ & $\%$ & $\mathrm{~F}$ & $\%$ & $\mathrm{~F}$ & $\%$ & $\mathrm{~F}$ & $\%$ & $\mathrm{~F}$ & $\%$ \\
\hline Very High & 8 & 20 & 9 & 22.5 & 8 & 20 & 3 & 7.5 & 12 & 30 \\
\hline High & 16 & 40 & 20 & 50 & 12 & 30 & 6 & 15 & 11 & 27.5 \\
\hline Medium & 13 & 32.5 & 10 & 25 & 18 & 45 & 22 & 55 & 12 & 30 \\
\hline Low & 2 & 5 & 0 & 0 & 1 & 2.5 & 8 & 20 & 4 & 10 \\
\hline Very Low & 1 & 2.5 & 1 & 2.5 & 1 & 2.5 & 1 & 2.5 & 1 & 2.5 \\
\hline Total & 40 & 100 & 40 & 100 & 40 & 100 & 40 & 100 & 40 & 100 \\
\hline
\end{tabular}

Table 6

Frequency Distribution for Subjective Well-Being

\begin{tabular}{lcccccc}
\hline \multirow{2}{*}{ Category } & \multicolumn{2}{c}{ Life Satisfaction } & \multicolumn{2}{c}{ Positive Effect } & \multicolumn{2}{c}{ Negative Effect } \\
\cline { 2 - 7 } \multicolumn{1}{c}{ Very High } & $\mathrm{F}$ & $\%$ & $\mathrm{~F}$ & $\%$ & $\mathrm{~F}$ & $\%$ \\
High & 8 & 20 & 4 & 10 & 8 & 20 \\
Medium & 15 & 37.5 & 7 & 17.5 & 11 & 27.5 \\
Low & 15 & 37.5 & 11 & 27.5 & 15 & 37.5 \\
Very Low & 1 & 2.5 & 15 & 37.5 & 5 & 12.5 \\
Total & 1 & 2.5 & 3 & 7.5 & 1 & 2.5 \\
\hline
\end{tabular}


Table 4 shows the results of correlation testing between the four sub-scales of perceived social support and negative effects respectively, those being: only self-esteem support showed a significant negative correlation with negative effects $(r=-.300 ; p=.011)$. This means that the subjects of the study will suffer low negative effects if they have someone who can provide self-esteem support. In this, what is meant by self-esteem support is the existence of someone who can raise the conviction of the subject regarding his or her ability to overcome problems, or complete a specific task.

The results of frequency distribution show that a large portion of the subjects of the study have a medium to very high degree of perceived social support, with the majority in the high classification (40\%). The results of frequency distribution for the perceived social support sub-scale show, of the four sub-scales, it was only regarding the self-esteem support subscale where the majority of the subjects fell into the low to medium classifications, with the majority in the medium classification (55\%). As for the other three sub-scales of perceived social support, the classification of the majority of subjects for the sub-scales of appraisal, belonging, and tangible support fell into the medium to very high levels. These results indicate that the contribution of self-esteem support was the lowest, compared to the other perceived social support subscales.

The results of frequency distribution for SWB indicate that a large portion of the subjects have life satisfaction levels classifiable as 'medium' to 'very high', with the majority in the classifications of 'medium' (37.5\%), and 'high' (37.5\%). A large portion of the subjects also had positive effects classifiable as 'low' to 'medium', with the majority in the 'low' classification $(37.5 \%)$, and had negative effects classifiable as at 'medium' to 'high' level, with the majority at the 'medium' level (37.5\%).

\section{Discussion}

Results of the data analysis of the study indicate there is a significant positive relationship between perceived social support and life satisfaction for retirees from the TNI - Army $(r=.420 ; p=.007$ ) (see Table 1). The existence of perceived social support during retirement can be an additional resource to overcome the demands faced by retirees. When entering retirement, people experience a lack of balance between life demands and the resources to surmount them. In retirement, there is a decline in financial and health matters, as well as in the matter of supportive social contacts, however people at this time have responsibilities towards two parties at the one time, their children and their parents (Papalia, Sterns, Feldman, \& Camp, 2007). This imbalance can make pensioners evaluate their lives as being unsatisfactory. People who have perceived social support (who consider their environs to be a provider of resources which may be accessed at any time) will feel more able to face challenges (demands) in life, or, in other words, assist in striking a balance between demands and resources. When they feel able to overcome demands, people will feel their lives to be classifiable as satisfactory.

The results of this study are in accord with the results of the study of Green, Nurius, and Lester (2013) which shows that there is a significant correlation between family stressors, family strain, social support, and the mental health of military wives. As is known, military wives are responsible for maintaining the balance and the psychosocial health of military families (Lara-Cinisomo et al., 2012; Palmer, 2008, as cited in Green, Nurius, \& Lester).

The results of this study are in line with those of the study by Ryser and Wernli (2017), which stated that retirement, or being unemployed, is often perceived negatively by society. Thus, people need to have a clear picture of the role changes involved when entering retirement. In this study, role changes in retirement for ex-members of the TNI may be accepted by family members and society as the coming of the conclusion of the period of service of a person as a servant of the state. Generally, TNI-Army retirees are quite valued by families or society. This social perception may thus raise their life satisfaction and mental health levels.

The results of correlation testing between the subscales of perceived social support and life satisfaction indicate a significant positive correlation between appraisal support $(r=.346 ; p=.029)$, tangible support $(r=.418 ; p=.007)$, and life satisfaction (see Table 2$)$. This indicates that (for the subjects of this study) people will have high life satisfaction when: they have someone who may be persuaded to talk to them, to discuss problems and assist in seeking the best strategy (appraisal support); as well as having someone who may give support or physical accompaniment, or support in the form of material goods or deeds (tangible support).

The results of this study also indicate the existence of a positive and significant connection between perceived social support and positive effects $(r=.667$; 
$p=.000)$ (see Table 1). Based on a positive correlational coefficient, the contribution given by perceived social support to positive effects is $44.5 \%$. A positive and significant correlational coefficient means that, the higher the level of perceived social support, the higher also is the level of positive effects felt by the individual. A significant and similarly directed connection between perceived social support and positive effects, indicated in this study, is in accordance with the results of study by Matsuda, Tsuda, Kim, and Deng (2014), which stated that perceived social support has a positive association with positive effects on tertiary student subjects.

The existence of a positive and significant correlation between perceived social support and positive effects indicates that a person having perceived social support will feel positive emotions. When entering retirement, there occurs a decline in the resources normally used to meet life demands. This situation is one of the matters which cause pensioners to evaluate retirement as a stressful life event. When a retiree has perceived social support, which may play a role as an additional resource in overcoming demands, he or she will feel more able to handle the demands encountered during retirement. The existence of additional resources will increase the ability and conviction of the individual as regards his or her ability to overcome the demands and challenges of life, so he or she may more easily feel positive emotions. This aside, the presence of thoughts or hopes that he or she may depend, or rely, upon others, when in need, is a matter which will cause a person to feel comfortable, and so contribute to his or her SWB (Siedlecki, Salthouse, Oishi, and Jeswani, 2013). In this, what is meant by comfort is that which causes an individual more easily to feel positive emotions. When a person feels comfortable (and does not feel pressured) he or she will more easily feel positive emotions in his or her daily activities.

In this study, the four sub-scales of perceived social support have significant positive correlations to positive effects (see Table 3 ). This indicates that the subjects of this study will experience high positive effects if they have someone who can: be persuaded to talk, to discuss problems and assist in seeking out the best strategy (appraisal support); be persuaded to complete an activity together (belonging support); raise his or her level of conviction concerning his or her ability to overcome problems, or to complete particular tasks (self-esteem support), and; provide support or physical accompaniment, or support in the form of material goods and deeds (tangible support).
Besides life satisfaction and positive effects, the other dimension of SWB is negative effects. In this study, perceived social support did not show a significant connection to negative effects $(r=-.208 ; p=$ .199) (see Table 1). The results of this study differed from those of the study conducted by Matsuda, Tsuda, Kim, and Deng (2014), which showed a negative and significant association between perceived social support and negative effects. This significant and negative association between perceived social support and negative effects in the study by Matsuda et al. indicated that, the higher the perceived social support which a person has, the lower will be the negative effects felt. The presence of thoughts or expectations of being able to depend upon/rely upon others when necessary is something which causes a person to feel comfortable, so contributing to his/her SWB (Siedlecki et al., 2013). Persons facing challenges or demands in life, who consider that their environment can be relied upon in overcoming those challenges, then tend to feel that such demands and challenges may be overcome. This thinking will cause a person to feel comfortable with his/her life (the person evaluates that such challenges or demands are not burdens). When a person feels comfortable with his/her life, the tendency to experience negative effects or emotions will be lower.

In this study, no connection between perceived social support and negative effects could be established, because of the existence of other factors, which made the negative effects for the subjects increase (free of a high perceived social support situation). These several factors, for instance, are related to low levels of self-esteem, displeasing life events, and to health or physical condition (Diener, 1984).

Poor physical condition will cause the individual to be susceptible to suffering negative emotions. In this, a large portion of the subjects of the study confessed to suffering physical complaints. According to Zautra and Hempel (as cited in Diener, 1984), subjective health has a strong connection with SWB. This means that, if an individual considers his or her physical condition to be poor, this will have an impact on the intensity of negative effects he or she experiences. A situation such as this said to be a cumulative "mental retirement" effect, that is the deterioration in cognitive function, suffered by people in retirement, in accordance with the adjustment (deterioration) of his or her health and socio-economic status (Clouston \& Denier, 2017).

In general, the majority of the subjects of this study had levels of life satisfaction classifiable as medium (37.5\%) and high (37.5\%), the level of positive 
effects for the majority of subjects was in the low category $(37.5 \%)$ and the level of negative effects for the majority of the subjects was in the medium category $(37.5 \%)$ (Table 6). The degree of negative effects (compared to positive effects) felt by the subjects was not unrelated to health conditions. In this study, a large portion of the study subjects claimed to have problems with their health. When people evaluated their health conditions as poor, they were more likely to suffer negative emotions, such as apprehension, worry, feeling under pressure, nervousness and fear. Besides this, the study subjects were, in the majority, male veterans $(77.5 \%)$, so this was in accordance with the results of the study by Ryser and Wernli (2017), that the quality of life for male pensioners is more easily influenced by their experiences in retirement, compared to that of female retirees. In Indonesian culture, the male is the backbone of the family, so that, post working life, his income, role and social contacts are reduced. This situation can influence the quality of life and mental health of male TNI-Army retirees.

As a result of the analysis covering the four subscales of perceived social support and negative effects, it was only self-esteem support which showed a negative and significant correlation (see Table 4). This means that the study subjects had low negative effects if they had someone who could offer self-esteem support. In this, what is meant by self-esteem support is the existence of someone who can increase the conviction of the subject in his or her ability overcome problems or complete certain tasks.

The results of frequency distribution for the subscales of perceived social support indicate that, of the four sub-scales, it was in only the self-esteem support sub-scale where the majority of subjects fell into the low to medium level classifications, with the majority in the medium level (55\%) (see Table 5). In the three other sub-scales of perceived social support, the classifications of the majority of the subjects in the sub-scales of appraisal, belonging, and tangible support were in the medium to very high classification levels (see Table 5). These results indicate that the self-esteem support contribution was the lowest, compared to the other perceived social support subscales.

Compared with the other sub-scales of perceived social support, that of self-esteem support was the most psychological form of support. This shows that, for the study subjects, physical support received greater appreciation (or was evaluated as being more readily available), compared with psychological support. By physical support, what was meant was support given which could be used directly, without having to go through a cognitive process or evaluation.

Although they had self-esteem support which was classifiable as being at a low to medium level, the major portion of the subjects had tangible support classifiable as being at medium to very high levels, with the majority in the classification levels of medium $(30 \%)$, high $(27.5 \%)$, and very high $(30 \%)$ (Table 5). The study by Schaefer et al. (as cited in Cohen \& Hoberman, 1983) indicated that their subjects aged between 45 and 64 years of age (middle aged) were more concerned with tangible/material requirements. The tangible support results, which were classified as being at medium to very high levels in this study, can be explained through the study by Schaefer et al., remembering all of the subjects of this study were in middle age.

\section{Limitations}

In the method used for this study, particularly regarding the sampling technique, the number and gender proportions of the subjects were not representative. Besides this, the efforts of the authors to unearth the problems of the stressors which often emerge amongst ex-members of the TNI, and the handling of these, covering who/which party handles them, and the nature of the results, as well as emergent problems often experienced, were not successfully obtained. It was thus also with the data of the TNI-Army retirees, for instance regarding stressful life events, resources of social support, psychological conditions, institutional efforts at the provision of mental health support to date, as well as the involvement of families in supporting mental health. What the results of this were, including if, periodically, there are joint activities held. These matters did not receive institutional authorization for disclosure, because of being categorized as secret, and not for publication. It is hoped, at another opportunity, that these important matters may be investigated via another, legal, approach, so that the study results may become more useful.

\section{Conclusion}

The results of this study indicate that TNI pensioners who are in retirement will be able to feel satisfaction in their lives. At the same time, TNI pensioners in retirement tend to be unable to feel happiness, or tend more to experience negative emotions. In this situation, perceived social support has a significant 
contribution for them. In this matter, perceived social support can give them the strength to face the challenges of life. This study indicates that the contribution of perceived social support towards life satisfaction is smaller $(17.6 \%)$ than the contribution of perceived social support to positive effects $(44.5 \%)$. The results of this study indicate that the sub-scales of perceived social support which are positively and significantly related to life satisfaction are those of appraisal support and tangible support. Positive effects have a positive and significant relationship to the four subscales of perceived social support, those being appraisal support, belonging support, self-esteem support, and tangible support, whilst self-esteem support is the only sub-scale of perceived social support which has a negative and significant connection with negative effects.

\section{Recommendations}

When going into retirement, it is hoped TNI pensioners, will maintain social contacts, for instance by joining specific organizations which they consider of interest, on a number of occasions each month meeting their friends, or contacting them via telephone, or using social media. Social contact, with friends and family, can assist in keeping relationships close, so that there will be an increase in the feelings that there are many people around them who care, and on whom they may rely.

It is hoped that people having retired friends and family members from the TNI, are prepared to give support when it is required, for instance by giving objective evaluations and seeking ways out of problems when asked for opinions or suggestions, expressing appreciation for his/her efforts and achievements, accompanying him/her in group activities, or giving support in deed or material form.

\section{References}

Butterworth, P., Gill, S. C., Rodgers, B., Anstey, K. J., Villamil, E., \& Melzer, D. (2006). Retirement and mental health: Analysis of the Australian national survey of mental health and well-being. Social Science \& Medicine, 62(5), 1179-1191.

Clouston, S. A. P., \& Denien, N. (2017). Mental retirement and health selection: Analysis from the US health and retirement study. Social Science and Medicine, 178, 78-86.

Cohen, S. (2004). Social relationships and health. American Psychologist, 59(8), 676-684.
Cohen, S., \& Hoberman, H. M. (1983). Positive events and social support as buffers of life change stress. Journal of Applied Social Psychology, 13(2), 99-125.

Diener, E (1984). Subjective well-being. Psychological Bulletin, 95(3), 542-575.

Diener, E., Emmons, R. A., Larsen, R. J., \& Griffin, S. (1985). The satisfaction with life scale. Journal of Personality Assessment, 49(1), 71-75.

Diener, E., Oishi, S., \& Lucas, R. E. (2003). Personality, culture, and subjective well-being: Emotional and cognitive evaluations of life. Annual Review Psychology, 54, 403-425.

Green, S., Nurius, P.S., \& Lester, P. (2013). Spouse psychological well-being: A keystone to military family health. Journal of Human Behavior and Social Environment, 23(6), 1-18.

Gülaçti, F. (2010). The effect of perceived social support on subjective well-being. Procedia Social and Behavioral Sciences, 2(2), 3844-3849.

Harms, P. D., Krasikova, D. V., Vanhove, A. J., Herian, M. N., Lester, P. B. (2013). Stress and emotional well-being in military organizations. The role of emotion and emotion regulation in job stress and well-being. Study in Occupational Stress and Well Being, 11, 103-132.

Heller-Sahlgren, G. (2017). Retirement blues. Journal of Health Economics, 54, 66-78.

Henning, G., Hansson, I., Berg, A. I., Lindwall, M., Johansson, B. (2017). The role of personality for subjective well being in the retirement transition - Comparing variable - and person - oriented model. Personality and Individual Differences, 116, 385-392.

Herzig, A. (2014). Optimizing well-being in retirement: Summarizing three decades of study on successful coping in retirement. Mind Pad, 4(7), 32-37.

Keyes, C. L., Ryff, C. D., \& Shmotkin, D. (2002). Optimizing well-being: The empirical encounter of two traditions. Journal of Personality and Social Psychology, 82(6), 1007-1022.

Kypraiou, A., Sarafis, P., Tsounis, A., Bitsi, G., Andreanide, E., Constantinidis, T., ... Malliarou, M. (2017). Depression and anxiety in Greek male veterans after retirement. Military Medicine, 182(3), e1639-e1644. https://doi.org/10.7205/ MIL MEDD-16-00299.

Latif, E. (2011). The impact of retirement on psychological well being in Canada. Journal of Socio-Economics, 40(4), 373-380.

Lin, C. C. (2015). The roles of social support and coping style in the relationship between gratitude and well-being. Personality and Individual Difference, 89, 13-18. 
Lucas, A. R., Daniel, F., Guadalupe, S., MassanaCardoso, I., Vicente, H. (2017). Time spent in retirement, health and well-being. European Psychiatry, 41(Supplement, April), S339-S340.

Matsuda, T., Tsuda, A., Kim, E., \& Deng, K. (2014). Association between perceived social support and subjective well-being among Japanese, Chinese, and Korean college students. Journal of Educational Psychology, 5, 491-499.

Papalia, D. E., Sterns, H. L., Feldman, R. D., \& Camp, C. J. (2007). Adult development and aging (3rd ed.). New York: McGraw-Hill.

Pflanz, M. S. (2001). Occupational stress and psychiatric illness in the military: Investigation of the relationship between occupational stress and mental illness among military mental health patients. Military Medicine, 166(6), 457-462.
Ryser, V. A., \& Wernli, B. (2017). How does transitioning into retirement impact the individual emotional system? Evidence from the Swiss context. Advances in Life Course Study, 32, 42-54.

Siedlecki, K. L., Salthouse, T. A., Oishi, S., \& Jeswani, S. (2013). The relationship between social support and subjective well-being across age. Social Indicator Study, 117(2), 561-567.

van der Heide, I., van Rijn, R. M., Robroek, S. J. W., Burdorf, A., \& Proper, K. I. (2013). Is retirement good for your health? A systematic review of longitudinal studies. BioMed Central Public Health, 13, 1180. https://doi.org/10.1186/1471-2458-13-1180.

Watson, D., Clark, L. A., \& Tellegen, A. (1988). Development and validation of brief measures of positive and negative affect: The PANAS Scales. Journal of Personality and Social Psychology, 47, 1063-1070. 